and what was called a Democrat wagon, having two seats: With this team and wagon I furnished the transportation for the delegation, and Van Buren county was represented in the State Convention by Abner H. McCrary, our State Senator from Van Buren county, Dr. William Craig, George C. Duffield and myself; I am the last one living. I had the honor also to be appointed one of the secretaries of this, the first Republican State Convention held in Iowa. It was the beginning of the political organization that has ever since, with the exception of a period of four years, controlled the legislation and policy of the State.

\title{
REPORT UPON THE PROPRIETY OF ABANDONING FORTS ARMSTRONG AND DES MOTNES.
}

Sir,--Your letter of the 17 th inst. reached me at St. Louis, and in due course of mail. The report which you direct me to make upon the propricty of abandoning Forts Armstrong and Des Moines, I will now present in the order pointed out by you.

1st. As to the expediency of breaking up the present establishment at Rock Island. The establishment of the fort in the first instance was with a view to the protection of our frontier citizens, in other words to aid in securing such control over the Indians thereabout as might at all times be exercised in a way to insure the general quiet. Whether the object contemplated has been obtained throughout need not now be enquired into, it is enough to know that the inquietude which dictated the order for the establishment of the fort is now dispelled by the removal of the Indians to a distant point and

\footnotetext{
1 The Historical Department recently received this document which, though not signed, has on it a memorandum, recently made, the substance of which is verifled in a letter from the Adjutant General of the United States as follows: "From a comparison of the enclosed manuscript with records on file, it is believed the handwriting of the manuscript is that of Colonel George Croghan, formerly Inspector General, United States Army. No report of Colonel Croghan containing information such as that contained in the manuscript has een tound on fle in this offlce."
} 
that there no longer exists a necessity for keeping up its gar-. rison: Let the post then be abandoned, but previously thereto, at all events simultaneously therewith, remove the Indian agency to the point which may be fixed upon for the military establishment at the same time withdraw the license granted to the trader at Rock Island that after the withdrawal of the troops the Indians may have neither excuse nor inducement for a continuance of their visits there, which cannot be made without attendant evil consequences, for invariably on his return home through the white settlements he is deprived as he would say unfairly of his purchases or presents. What can follow but a burning desire to revenge himself upon the first white man he may meet, for they are all in his eye equally guilty of the fraud which has been practiced upon him.

2d. The place which should be selected upon the Des Moines. Agreeably to your instructions, I have conversed freely on this subject with both Lit. Cols. Davenport and Kearney. Lt. Col. D. I found well informed upon all matters relating to the Sauk \& Fox Indians and though he did not disagree with me as to inutility of continuing a garrison upon Rock Island he seemed rather to question the propriety of breaking it up immediately for the purpose of establishing it. upon the Des Moines, which river he thinks possesses not the same military advantages that are held out by the lower Ioway river.

Col. K. is decidedly opposed to the establishment of a garrison.upon any part of the Des Moines, or indeed to the erection of any new forts. He would give the garrison at Fort Armstrong either to Prairie du Chien or St. Peters, insisting upon it that. with his command of dragoons he can keep the peace of all the country thereabouts. I question his ability to perform the service he will take upon himself. I would not express a doubt about his trying. At all events to insure him success as far as practicable, it would be necessary to arm him with power to punish forthwith such whites as he might find trespassing upon the Indian lands, for to such scoundrels half the Indian outrages may invariably be traced. 
Since my note to you of the 25 th Dec. I have had frequent conversations with Gen. Clark and other gentlemen, the best informed upon the subject which I have under consideration. All agree with me in the propriety of breaking up Fort Armstrong but they cannot so readily fix upon a point on the Des Moines to which its garrison shall be sent, being unacquainted with the navigable character of the river.

Left then in a great measure to my own judgment in the case, and required by you to designate some place for a military location, I will fix upon the mouth of the Raccoon fork as combining perhaps more advantages than are presented by any other point on the river. It is very nearly, if not equally accessible by water as Cedar Point, and is besides much farther removet from the Missouri state line than that point, a circumstance not to be forgotten when recollecting that the Indians when not upon their hunting grounds will most genwally be about the agrency and trading horses, be they near or at a distance from the white settlements and it should be a care to keep them as far as possible separated. You will perceive by the accompanying map that Raccoon fork is 50 miles $\mathrm{N}$. of the Missouri line.

The Upper fork of the Des Moines is not without its advantages and could it be provisioned as easily as the Raccoon fork (and it might be for ought I know) it might be esteemed the most eligible situation of the two from its admirable location with respect to Council Bluffs and St. Peters, being directly in a line between the two and not more than 125 miles from either, and more than this it lies within the neutral ground separating the Sauk and Sioux upon which both tribes wish that i garrison should be located. Keokuck has already expressed great unwillingness to the erection of a fort upon the Des Moines unless it be upon the neutral ground as above stated. Did I know more particularly your views with respect to our Indian relations I should perhaps not feel so much at a loss in determining a military position on the Des Moines the best calculated to meet them. If your sole object in erecting a fort upon the Des Moines be the preserva- 
tion of the peace between the whites and the Sac and Fox tribes of Indians, I should advise its location lower down so as to interpose between the white settlements and the Indian towns, but believing that peace with the Sioux is also considered by you it is therefore that I have located at the Raccoon fork as a point as more likely to be properly considered by that trube.

If it be intended in the arrangements of our military forts not only to protect ourselves from Indian outrages but at the same time to keep the peace among the several tribes themselves, the end cannot be secured without the occupancy of some point about the Council Bluffs, at all events above the by [?] river Platte. We are bound in honor to secure the immigrating Indians against danger from the powerful tribes above them on the Missouri and its tributaries and it cannot be done under existing circumstances. I would then recommend that one entire regiment of infantry occupy some point above the Platte and that the Regiment of Dragoons be stationed (when not on distant. service) at Fort Leavenworth. But let the decision with respect to the Regiment of Infantry be as it may, I would advise that [?] Leavenworth be given up exclusively to the Dragoons and that Lt. Col. Kearney's command be ordered there, at least as soon as the barracks which he now occupies becomes unhabitable. Yours 3d January then with respect to the present Dragoons location $\mathrm{N}$. of the Missouri is now answered. Having directed your inquiries with [?] relation to the Des Moines I may be traveling somewhat out of the line pointed out, but it may not be unpleasing to you that I should continue on and state my reasons for the occupancy of some place about the Council Bluffs.

The establishment of such a fort is essential.

1st. In consequence of the approximation of our white settlements to Indians who have claimed and occupied the country adjacent to that point since our earliest intercourse with them.

2nd. The position assigned to the Potowotomies, and which will be assigned to other immigrating Indians, and $3 \mathrm{~d}$, 
the influence which it exerts over the great nation of Sioux of the Missouri river, who if conjecture be verified, will very soon be joined by all the Sioux of the St. Peters.

The Indians in the immediate vicinity of the fort in question are the Ottos and Missouris 25 miles distant from Council Bluffs on the Platte, the Omahas and Puncas ( 70 or 80 miles above on the Missouri S. side). Several bands of the Pawnees (a powerful and turbulent nation) to the west about 150 miles in the rear and on the $\mathrm{N}$. side of the Missouri from the boundary of the State to a point 100 miles above the Bluffs having been in part assigned to immigrating Indians and the residue alloted as a common hunting ground to all Indians who were parties to the treaty of Prairie du Chien in 1830. A battle field is thus prepared for every party thus privileged. But in view of the combustible material here already collected and increasing it will be borne in mind that the country of the Missouri Sioux commences only 100 miles above the Council Bluffs and extends up the Missouri river many hundreds of miles, inhabited by the most powerful and warlike tribes of. Indians with whom we had intercourse. Conviction must then force itself upon you that sooner or later conflicts must take place. The Indians below will extend their excursions as game becomes scarce, into the country of the Sioux above, and that retaliation which is a consequence of such trespass will be visited surely in some unpleasant shape or another, unless it be prevented by a military force. My reasoning may not convince you but my conviction is that Council Bluffs is the most important military position between the Gulf of Mexico and the Red river of Lake Winnipeg, and further that its importance will continue to increase in proportion to the increase of Indians and whites in its vicinity. 
Copyright of Annals of Iowa is the property of State of Iowa, by \& through the State Historical Society of Iowa and its content may not be copied or emailed to multiple sites or posted to a listserv without the copyright holder's express written permission. However, users may print, download, or email articles for individual use. 